\title{
気体透過式粉体比表面積測定法における Kozeny定数の検討*
}

\author{
森 祐 行 ${ }^{1}$ 野中壮泰 ${ }^{2}$ 岡本 寿 夫 $^{3}$
}

\author{
A Study on the Constant of Kozeny-Carman's Equation for the Determination of \\ the Specific Surface Area of Particles by the Permeability Method \\ by Sukeyuki MORI ${ }^{1}$, Moriyasu NONAKA ${ }^{1}$ and Hisao OKAMOTO ${ }^{2}$ \\ 1. Faculty of Engineering, Kyushu University, Higashi-ku, Fukuoka 812 \\ 2. Faculty of Science, Kyushu University
}

\begin{abstract}
Kozeny-Carman's equation is used for the determination of the specific surface area of particles by gas permeametry. We found that using this equation the measured values of particle size under the same experimental conditions vary widely. After conducting many experiments, a scatter in measured values of specific surface area of particles was obtained. However, the obtained scatter of points is thought not to be due solely to experimental error, but they suggests that the value of $K$ is not a constant but is infact variable. Using glass spheres of known density and specific surface area, we proceeded to calculate the value of $K$.

The sorted glass spheres were prepared by the following procedure. Toshiba glass beads (\#GB741) were sieved using JIS standard screens $(-420+350 \mu \mathrm{m})$, decantated and nonspherical particles were removed using an inclined rotating circular plate. The mean particle diameter, specific surface area and density of the glass spheres are $362.5 \mu \mathrm{m}, 165.5 \mathrm{~cm}^{2} / \mathrm{cm}^{3}$ and $2.50 \mathrm{~g} / \mathrm{cm}^{3}$, respectively. The experiments were repeated under the same conditions as follows:

Sectional area of the cylindrical cell $A$ is $32.047 \mathrm{~cm}^{2}$, the coefficient of viscosity of the nitrogen gas at $20^{\circ} \mathrm{C}$ $\eta$ is $1.766 \times 10^{-5} \mathrm{P}_{\mathrm{a}} \cdot \mathrm{s}$, and the weights of the glass spheres are $200,430,860$ and $1,290 \mathrm{~g}$.

The experimental results obtained are as follows:

(1) The values of Kozeny constant $K$ obtained by the reverse calculation technique vary widely, and the distribution curves of the values of $K$ are shown as normal distributions.

(2) In the case where the weight of the glass spheres is $200,430,860$ and 1,290 g, the mean values of the constant $K$ are found to be $4.478 \pm 0.3234,4.584 \pm 0.1844,4.602 \pm 0.1168$ and $4.582 \pm 0.0883$ and the number of repetitions are 210, 90, 90 and 80 times, respectively.
\end{abstract}

KEY WORDS: Particle Diameter, Specific Surface Area, Permeability, Kozeny Constant

\section{1. はじめに}

粉体の粒度は, 粉体の性質を表わす基本的な数值の一つであり, 粉体を取り扱う多くの操作において重要な役割を果たしている。 特に, 粉体粒子の表面の性質が影響するような諸操作においては, 粉体の比表面積を測定することが必要である。比表面積の測定法 としては, 透過法, 吸着法, 浸漬熱法, 拡散速度法, 溶解および 反応速度法などがあげられるが，透過法は，他の測定法にくらべ て装置や操作が簡単で, 短時間で測定できる利点をもっている。 この方法は, 粉体の充填層を通る流体の正力降下と流量を測定し, Kozeny-Carman の式を用いて比表面積を求めるものである ${ }^{1) 2 ） 。 ~}$ この気体透過法の理論式である Kozeny-Carmanの式は, 一般 によく利用されているが, 実際にはかなりの問題を含んでいる ${ }^{3)}$ 。

* 1990 年 11 月 17 日受付 1992 年 4 月 3 日受理 資源・素材学会 平成 2 年度春季大会にて発表

1. 正会員 工博 九州大学教授 工学部資源工学科

2. 学生会員 九州大学大学院工学研究科資源工学専攻

3. 理博 九州大学助教授 理学部物理学科

キーワード : 粒子径, 比表面積, 透過率, コゼニ一定数
式中の Kozeny 定数 $K$ は, Carmanによって半実験的に 5 と定めら れている ${ }^{4)}$ が, 粒子の形状や充填度によって影響を受けるという 報告もある ${ }^{3)}$ 。

そこで, 今回は，粒子の形状や充媜度の影響をなくするために， 比表面積および密度を正確に求めた整粒球形ガラスビーズを作製 し，透過試験を行うことで，これら 2 つ因子以外でどのような 因子がKozeny 定数に影響を与えるのかを調べた。その時, 試料 層の長さを変えることにより，4種の試料層長さで実験を行い, 試料層の長さの Kozeny 定数に与える影響を調べることとした。 さらに, 同一条件下で数多くの実験を行い, Kozeny 定数のばら つきの性格についても検討した。

\section{2. 試料}

\section{$2 \cdot 1$ 試料の調製}

粉体試料として, 東芝ガラスビーズ(東芝バロディー二(株)製） を用いた。このガラスビーズは研磨剤として市販されていて, 各 種の製品は各粒度毎にある程度サイジングされている。今回は, そのうちの製品名GB 741 のガラスビーズから次のような方法で 


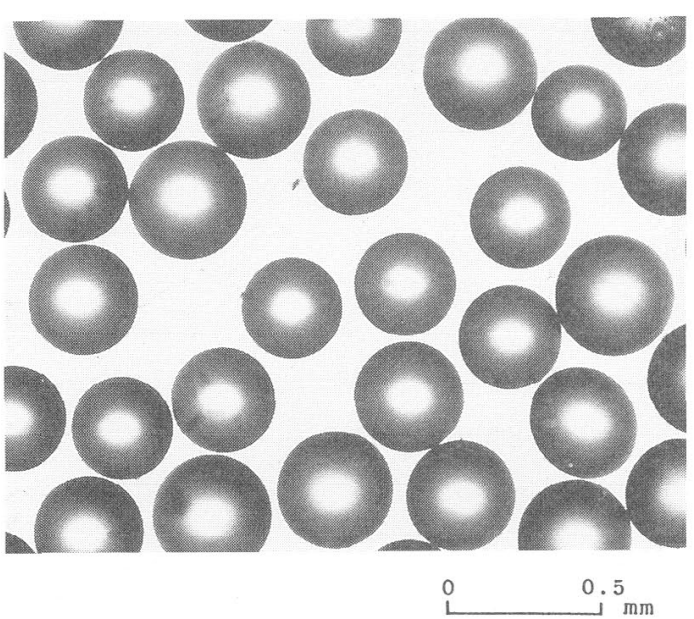

図 1 試料の顕微鏡写真

非球形粒子を取り除き,デカンテーションを行い, サイジングし て，球形の整粒試料を調製した。

まず, G B 741 のガラスビーズを J I S の標準ふるいを用いて ふるい分けし，内部に気泡の混入しているガラスビーズ，粒子表 面の污れ，ほこり等を除去するためビーカにガラスビーズを入れ， 水を加えて熼拌の後上澄液を流し出す操作 (デカンテーション) を行った。さらに，傾斜させた回転盤の上で粒子を転がし，ほぼ 真下に転がっていく粒子のみを採取することで，非球形粒子を除 去し，球形粒子を得ることができた。今回用いた試料は，上記の うち- $420+350 \mu \mathrm{m}(-36+42 \mathrm{mesh})$ の整粒球形ガラスビーズ ( 試料名：G B - C ) である。実験に用いた試料の顕微鏡写真を図 1 に示す。

\section{$2 \cdot 2$ 比表面積の測定}

万能投影機を用いた顕微鏡法によって試料の平均粒径および比 表面積を測定した。まず，1,000個以上のガラスビーズ粒子とマイ クロメータをポラロイドフィルムに撮影し, ついで, マイクロメ 一タの目盛りを基準にして, 写真上の 1 個 1 個の粒子の粒子径を ノギスで測定した。

試料の平均粒子径 $D_{s}(\mathrm{~mm})$ は, 次式で計算した。

$$
D_{s}=\frac{\sum d_{i}{ }^{3} \cdot n_{i}}{\sum d_{i}{ }^{2} \cdot n_{i}}
$$

ここで, $d_{i}$ は $i$ 番目の粒子径区分の粒子の相乗平均径 $(\mu \mathrm{m}), n_{i}$ は $i$ 番目の粒径区分の粒子の個数である。

また, 比表面積 $S_{v}\left(\mathrm{~cm}^{2} / \mathrm{cm}^{3}\right)$ は, 次式で計算した。

$$
\begin{aligned}
& S_{v}=\frac{\sum 4 \pi\left(d_{i} / 2\right)^{2} \cdot n_{i}}{\sum 4 \pi\left(d_{i} / 2\right)^{3} \cdot n_{i} / 3} \\
& =6 \cdot \frac{\Sigma d_{i}{ }^{2} \cdot n_{i}}{\Sigma d_{i}{ }^{3} \cdot n_{i}} \\
& =\frac{6}{D_{s}}
\end{aligned}
$$

測定の結果, 試料 ( G B - C ) の平均粒径 $D_{s}$ は $362.5 \mu \mathrm{m}$, 比表面 積 $S_{v}$ は $165.5 \mathrm{~cm}^{2} / \mathrm{cm}^{3}$ であった。

\section{$2 \cdot 3$ 密度測定}

試料の密度 $\rho$ は, 比重天科法によって測定した。その結果, $\rho$ $=2.50 \mathrm{~g} / \mathrm{cm}^{3}$ であった。

\section{3. 実 験 装 置}

実験装置は, 試料充塤層を含む試料セル, 差王計, および流量 計との組合せからなっている。今回使用した装置は, Lea-Nurse

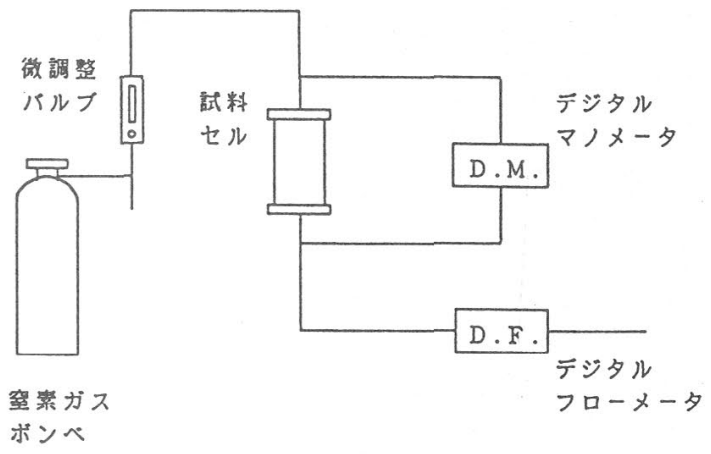

図 2 実験装置模式図

法を参考にして製作した装置であり ${ }^{5) 6)}$ ，実験装置の模式図を図 2 に示す。今回の実験では, 圧力降下をデジタルマノメータ, 流 量をデジタルフローメータを用いて測定した。

試料セルは, アクリル製の円筒形セル ( セル名称 : $\mathrm{E}-3$, 直径 約 $64 \mathrm{~mm}$, 高さ $31.553 \mathrm{~cm}$ ) を用いた。このセルの断面積 $A$ は $32.047 \mathrm{~cm}^{2}$ である。

粉体層を通寸気体には窒素ガスを用いた。窒素ガスの $20{ }^{\circ} \mathrm{Cにお}$ ける粘性係数りは $1.766 \times 10^{-5} \mathrm{P}_{\mathrm{a}}$ ・sである ${ }^{7) 8)}$ 。

\section{Kozeny 定数の逆算法}

粉体の比表面積を求めるKozeny-Carman の式を(3)式に示 す 1)4) 9)

$$
\begin{aligned}
& S_{v}=\sqrt{\frac{g \cdot A}{K \cdot \eta \cdot L} \cdot \frac{\Delta p}{Q / t} \cdot \frac{\varepsilon^{3}}{(1-\varepsilon)^{2}}} \ldots \ldots \ldots \ldots \ldots \ldots \ldots \ldots \ldots \ldots \\
& \varepsilon=1-\frac{W}{\rho \cdot A \cdot L}
\end{aligned}
$$

ここで, $K$ はコゼニ一定数, クは窒素ガスの粘性係数 $\left(\mathrm{P}_{\mathrm{a}} \cdot \mathrm{s}\right), g$ は福岡市における重力加速度で $979.63\left(\mathrm{~cm} / \mathrm{s}^{2}\right)^{10)}, S_{v}$ は比表面 積 $\left(\mathrm{cm}^{2} / \mathrm{cm}^{3}\right), A$ は断面積 $\left(\mathrm{cm}^{2}\right), \rho$ は試料密度 $\left(\mathrm{g} / \mathrm{cm}^{3}\right), W$ は 試料重量 $(\mathrm{g}), L$ は試料層長さ $(\mathrm{cm}), \Delta p$ は圧力降下 $\left(\mathrm{g} / \mathrm{cm}^{2}\right)$, $Q / t$ は流量 $\left(\mathrm{cm}^{3} / \mathrm{s}\right), \varepsilon$ は空隙率 $($ 一) である。

Kozeny-Carmanの式を変形して定数Kを逆算する式は次のよ うになる。

$$
K=\frac{g \cdot A}{\eta \cdot L \cdot S_{v}^{2}} \cdot \frac{\Delta p}{Q / t} \cdot \frac{\varepsilon^{3}}{(1-\varepsilon)^{2}}
$$

実験に際しては, 比表面積を正確に求めた試料を使用するので, (5)式において， $S_{v}$ の值は実験に使用する試料を決定した時点で決 まる。また, 試料層の断面積 $A$ は, 使用する試料セルを決定した 時点で決まる。従って, (5)式に扔いて, $\eta, g, S_{v}, A, \rho$ はおの 扔の定数となるので，実験の度ごとに測定しなければならない値 はW, $L, \Delta p, Q / t$ となる。

\section{5. 流量の補正}

実験では, 圧力降下をデジタルマノメータで, 流量をデジタル フローメータで抒のおの測定した。デジタルマノメータは, 試料 セルの入口の圧力と出口の圧力との差仕を測定する装置で, 試料 セルに対して並列に接続してある。

デジタルフローメータは, 試料セルを通過する気体（今回は窒 素ガス) の流量を測定する装置で, 試料セルに対して直列に接続 してある。ただし，この装置に表示される数值は，直接的には流 量を示していないので, この数值を流量に換算し, さらに圧力補 正を行った。

\section{$5 \cdot 1$ 流量への換算}

実験に先立ち、デジタルフローメータの読みが石醶膜流量計で 


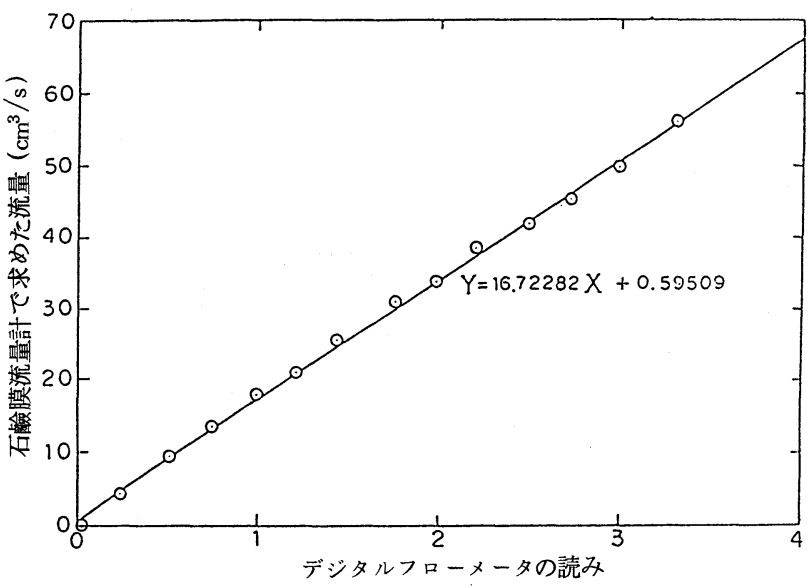

図3 デジタルフローメータの読みと石瞼膜流量計で 求めた流量との関係

求めた流量 $\left(\mathrm{cm}^{3} / \mathrm{s}\right)$ とどう対応するかを調べるためにグラフ上に プロットし，さらに，それを最小自乗法で一次近似し，その関係 式を求めた。その結果を図了に示す。その時の関係式は,

$Y=16.72282 \mathrm{X}+0.59509$ $(6)$

であった。

実験中のデジタルフローメータの読みを(6)式の $X に$ 代入して $Y$ を求める。こうして得られた $Y$ の値が流量値となる。

\section{$5 \cdot 2$ 流量值の圧力補正}

(6)式から得られた流量值は大気压下で測定された值であり，加 圧された試料セル中での值とは異なることになる。そこで，大気 圧下で測定した流量を試料セル中を流れる加圧下の流量に補正す る必要がある。流量の圷力補正の概念図を図 4 に示し，その補正 法を以下に示す。

図 4 に示すように, 大気圧を $P_{a}$, 試料セルの入口と出口の差臣 を $\Delta p$ とすると試料セルの入口の圧力は, $P_{a}+\Delta p$, 出口の臣力 は $P_{a}$ と表わされる。ここで, 試料セル内部の圧力を, 入口と出口 の圧力の平均とすると,

$$
\text { 試料セル内部の圧力 }=\frac{P_{a}+P_{a}+\Delta p}{2}
$$

と表わされる。また, 大気圧下の流量を $(Q / t)_{o b s}$, 試料セル中の 流量を $(Q / t)$ とおくと, 圧力と流量の関係から次式が成り立つ。

$$
\frac{P_{a}+P_{a}+\Delta p}{2} \cdot(Q / t)=P_{a} \cdot(Q / t)_{o b s}
$$

よって, 試料セル中の流量 $(Q / t)$ は, 次式によって決定される。

$$
(Q / t)=(Q / t)_{o b s} \cdot \frac{2 P_{a}}{2 P_{a}+\Delta p}
$$

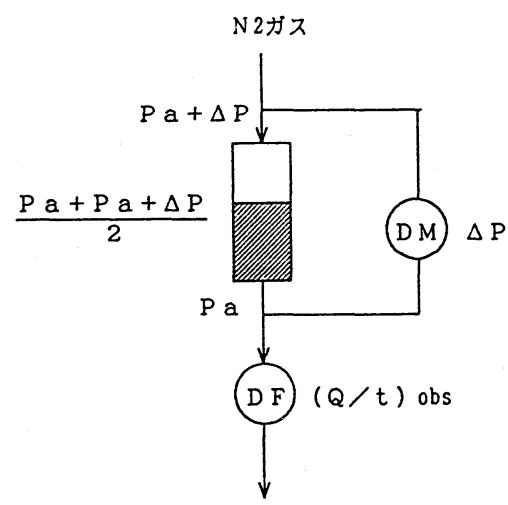

図 4 流量の圧力補正の概念図

\section{6. 実 験 方 法}

実験によって求めた試料セル両端の差王 $\Delta p$ と流量 $Q / t$ の関係 を図 5 に示す。定数 $K$ を求めるには, 図 5 に示すように, 流量 $(Q / t)$ と差圧 $\Delta p$ を測定すれば良いことになるが,ここで得られ る $\Delta p$ は試料セルや装置が持つ内部抵抗と粉体層自身の持つ抵抗 を加えた值となる。そこで，この内部抵抗の影響を除くために， 試料セルに試料を充填したときに得られる流量一差王のグラフか ら，試料セルや装置自身が持つ抵抗を差し引かなければならない。 そこで，まず試料セルに試料を入れない状態で窒素ガスを流し， 装置自身の流量と差压の関係を求める。これをwi thout sample と名付けた。この関係を最小自乗法で二次近似したグラフの一例 が図 5 の 1 の曲線である。次に重量 $W(\mathrm{~g})$ の試料を試料セルに入 れて, 試料層長さ $L(\mathrm{~cm})$ を測定した後, 同様に窒素ガスを流し, 流量と差王の関係を求める。これをwith sample と名付けた。 この関係を最小自乗法で二次近似したグラフの一例が図 5 の 2 の 曲線である。そして, 2 の曲線のwith sample から 1 の曲線の without sampleを差し引くと, これが試料層のみの流量と差壬 の関係であり, only sampleと名付けた。この関係を最小自乗法 で一次近似すると図 5 の 3 の直線になる。この時の直線の傾きが $\Delta p /(Q / t)$ であり，試料のみの抵抗を示している。この值を(5) 式に代入すると, Kozeny 定数 $K$ が求まる。おのおのの実験におい ては，おのおのに図 5 を描き, 図の only sample が直線になる ことを確かめ, 直線になる範囲内においてのみ実験を行った。

この一連の手順において, 1 回 1 回の実験の度に, 試料の詰め 替えを行い without sample から測定を始めるのだが，このと き詰め替えを行ってもできるだけ空陌率が一定になるようにする ため, 試料を試料セルに入れ、るとき, 試料を科り取るために使用 したビーカの注ぎロを, 試料セル上端の中央部に持ってきて, 試 料の注入速度を一定にするように心掛けた。なお, 現象を複雑に しないために，すべての測定においてタッピングは行わなかった。 以上の手順で 1 回の実験が完了し, Kozeny 定数 $K$ が逆算され る。この実験を試料重量が $200 \mathrm{~g}, 430 \mathrm{~g}, 860 \mathrm{~g}, 1,290 \mathrm{~g}$ の 4 種類 で繰り返した。なおおのおのの実験回数は，210回，90回，90回， 80 回である。本論文では, 集まった実験データを統計処理するこ とで結果を出した。

\section{7. 結果および考察}

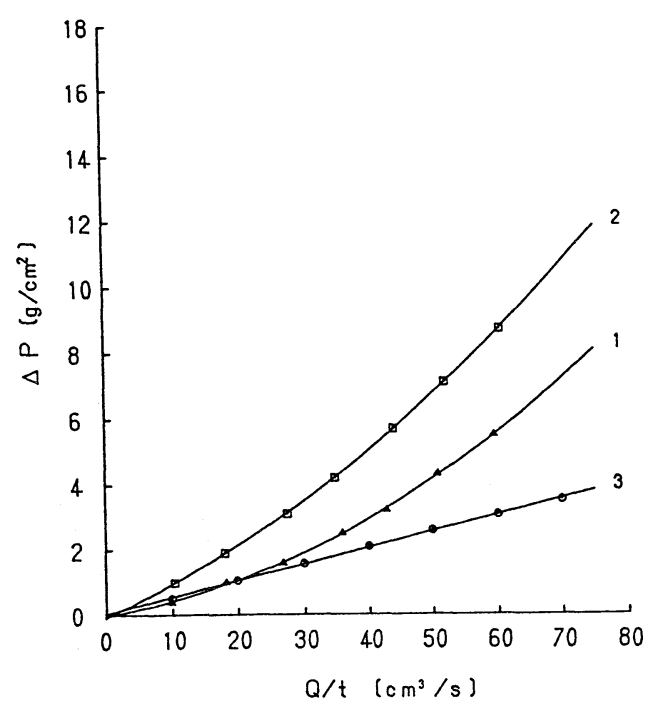

図 5 試料セル両端の差压 $\Delta p$ と流量 $Q / t$ の関係 


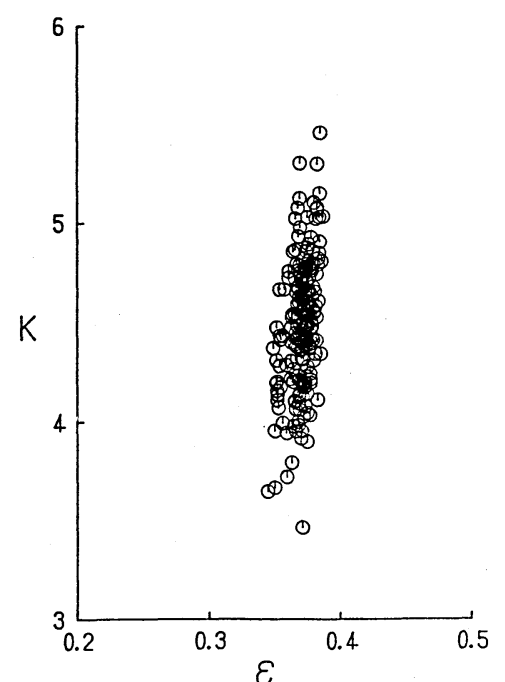

図6 $\varepsilon$ と $K$ の関係 $(W=200 \mathrm{~g}, n=210)$

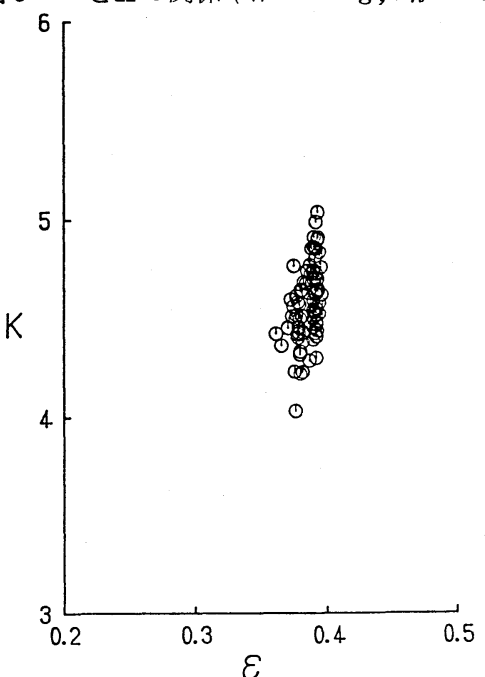

図 $7 \varepsilon$ と $K$ の関係 $(W=430 \mathrm{~g}, n=90)$

$7 \cdot 1$ 空隙率 $\varepsilon$ とKozeny 定数 $K$ の関係

空隙率 $\varepsilon$ と Kozeny 定数 $K$ の関係を図 6, 7, 8,9に示す。空 隙率については, 実験方法で述べたように, 1 回 1 回の測定にお ける試料の詰め替えでもできるだけ一定になるようにと配慮した ので, 図 $6,7,8,9$ の空隙率 $\varepsilon$ と定数 $K$ の関係のグラフに見る ようにかなり狭い範囲に集中している。にもかかわらず，定数 $K$ はばらついておう, 空隙率 $\varepsilon$ と定数 $K$ との間に明確な関連性は見 いだせない。このとき, $\varepsilon$ の分布範囲は, 試料重量 $200 \mathrm{~g}$ の時 $0.3440 \sim 0.3867,430 \mathrm{~g}$ の時 $0.3605 \sim 0.3953,860 \mathrm{~g}$ の時 0.3707 〜 $0.4009,1,290 \mathrm{~g}$ の時 $0.3801 \sim 0.4021$ であった。

$7 \cdot 2$ Kozeny 定数 $\boldsymbol{K}$ のばらつき

実験で得られた測定值を統計的に処理する場合, 数個のデータ から, その平均値をもって真の值のように扱うのは, 普通行われ ている手法である。この時, 平均值が真の值であるための条件と は，測定値のばらつきが正規分布になるということである。そし て，まれではあるが正規分布にならない例もある。例えば，近年 になって研究が盛んになった非線形系のカオス現象から得られる 時系列データは，正規分布にならない。従って，カオスの現象で は平均值や分散が決定できない例が多数知られている ${ }^{11) 12 ｝ \text { 。 }$

今回, Kozeny 定数そのものを検討するために, 同一条件で得 られた多数のデータを統計処理するに際し, 平均値や標準偏差を 論ずる前に，まずその分布から調べた。

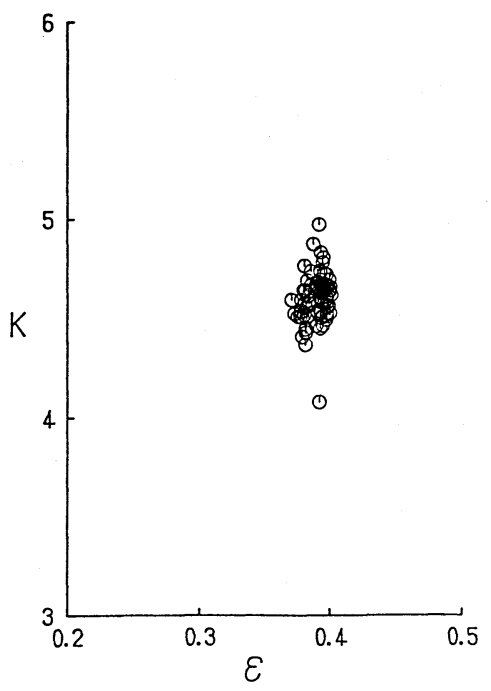

図8 $\varepsilon$ と $K$ の関係 $(\mathrm{W}=860 \mathrm{~g}, n=90)$

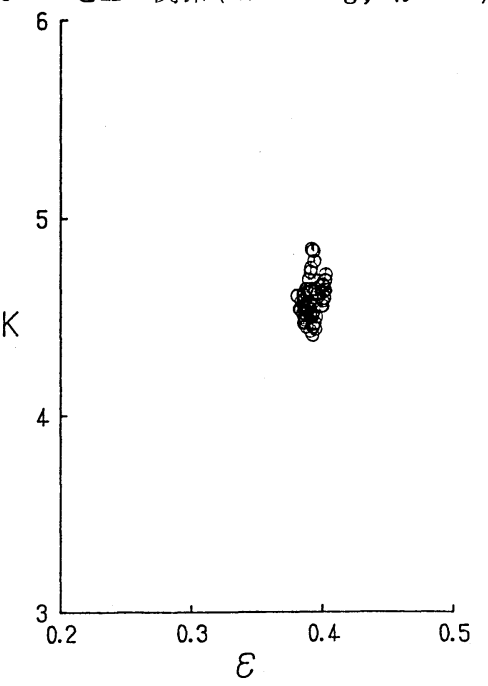

図9 $\varepsilon$ と $K$ の関係 $(W=1,290 \mathrm{~g}, n=80)$

図10，11，12，13 に測定して得られたKozeny 定数 $K$ の值を 個数頻度のヒストグラムとして示す。図に示されるように, どの 試料重量の時もKの值はかなりのばらつきを持っている。

図14に, 測定して得られた Kozeny 定数 $K$ の値を正規確率紙上 に個数頻度を積算した時の積算\%グラフとして示す。図に示され るように, どの試料重量の場合もデータは直線上に並んでいる。 正規確率紙上でプロットしたデータが直線に並ぶということは, そのデータが正規分布であることを意味する。よって，Kのばら つきは正規分布をしていると考えられる。また, 眓において, 試 料重量が大きいほど直線の傾きは大きくなっている。正規確率紙 上で, 直線の傾きが大きいということは, 分布の幅が小さいとい うことを意味している。ここで, それぞれの試料重量における実 験回数, 平均試料層長さ $L_{m}, K$ の平均値 $K_{m}$, 標準偏差 $\sigma$ をま之 めて表 1 に示す。また, 平均試料層長さ $L_{m}$ と定数 $K$ の関係を図 15に示す。図において, 口印が平均值 $K_{m}$, 粎線の長さが標準 偏差を表わしている。図14, 表1, 図15に示されるように, 試料重 量が大きいほど, つまり, 試料層長さが長くなるほど分布の幅は 小さくなっているといえる。

なお, それぞれの試料重量での定数 $K$ の平均値と標準偏差は, 表 1 に示寸值となっているが, 各試料重量における $K_{m}$ の単純平 均值は 4.562 となっている。ここで, $K=4.562$ の場合と $K=5$ の 場合の比表面積を比較してみると, (3)式から, 


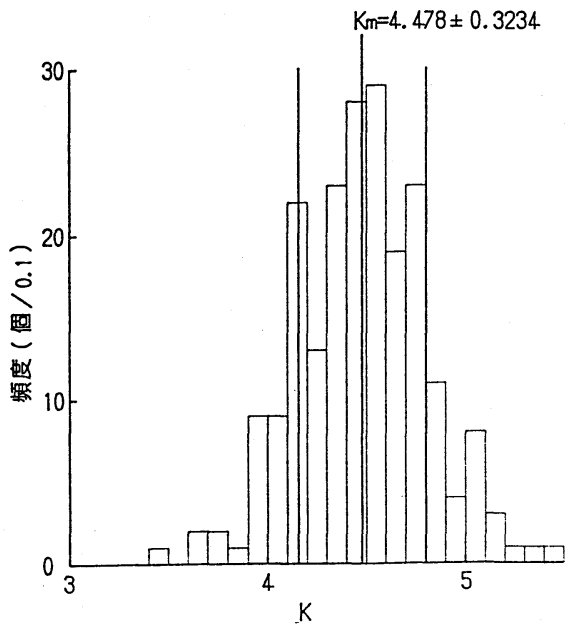

図10 $K$ の頻度分布ヒストグラム $(W=200 \mathrm{~g}, n=210)$

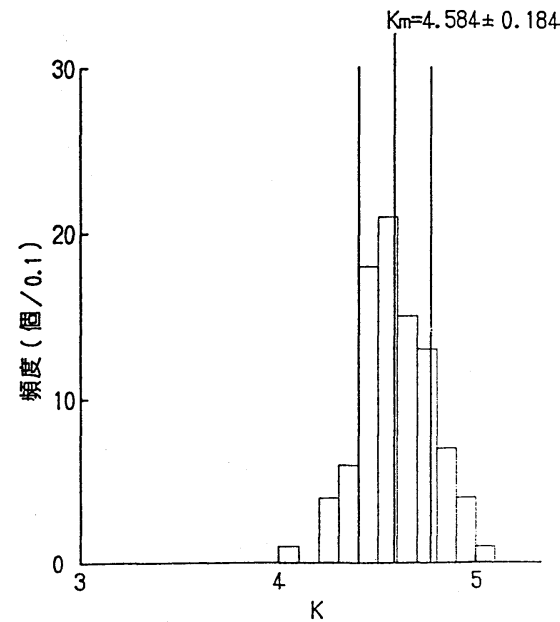

図11 $K$ の頻度分布ヒストグラム $(W=430 \mathrm{~g}, n=90)$

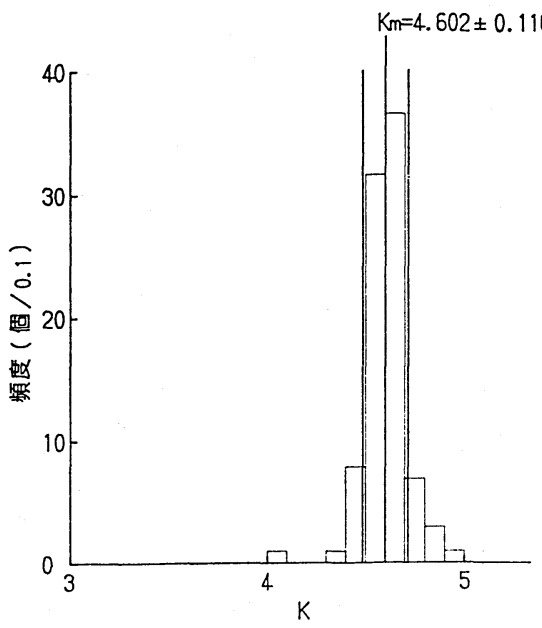

図12 Kの頻度分布ヒストグラム $(W=860 \mathrm{~g}, n=90)$

$S_{V(K=5)} / S_{V(K=4.562)}=0.955$

となり, $K=5$ とした時は $K=4.562$ とした時の 0.955 倍となる。 従って, もし $K=5$ の值を用いれば，本実験に用いた試料の比表 面積 $165.5 \mathrm{~cm}^{2} / \mathrm{cm}^{3}$ は $158.1 \mathrm{~cm}^{2} / \mathrm{cm}^{3}$ となり, 実際の比表面積よ り小さな值となる。

$7 \cdot 3$ Kozeny 定数 $\boldsymbol{K}$ の検討

試料セル中の粉体層を通る流体は，粉体粒子の隙間を通って流 れる。気体透過法における Kozeny-Carman の式においては，

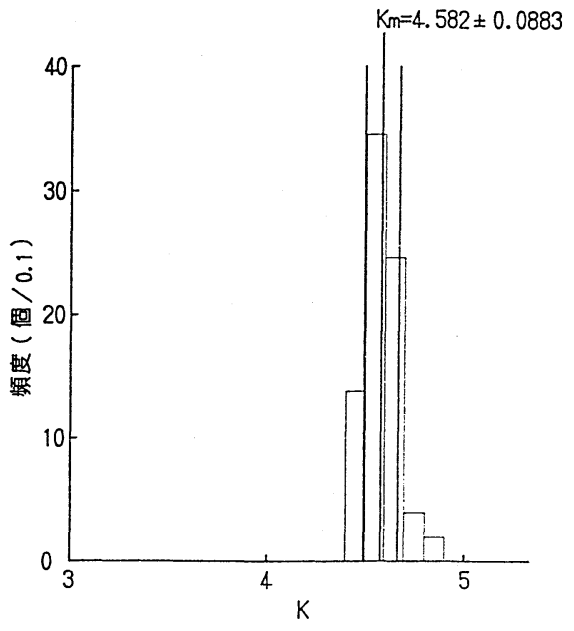

図13 Kの頻度分布ヒストグラム $(W=1,290 \mathrm{~g}, n=80)$

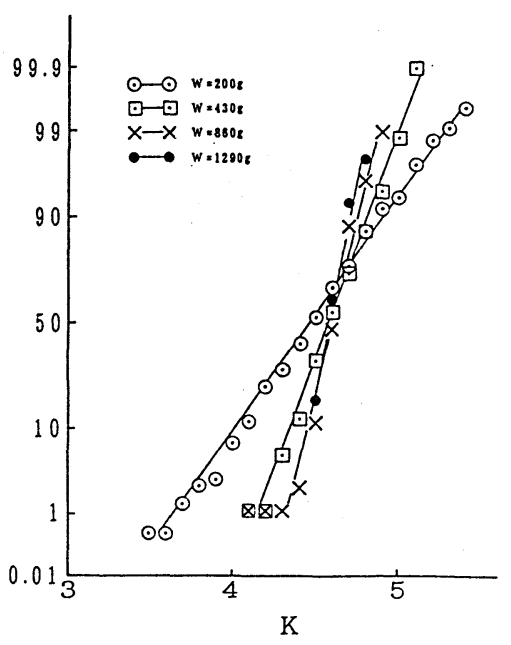

図14 Kの積算\%分布（正規確率紙）

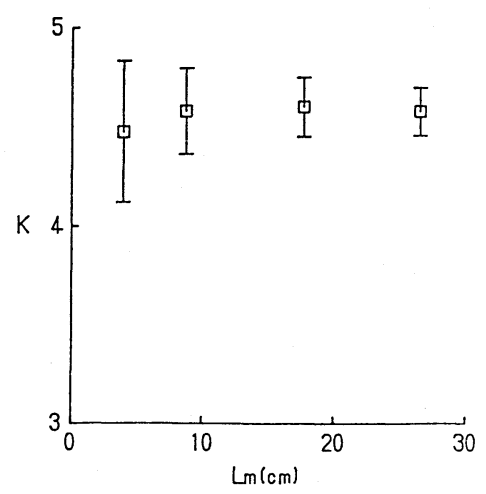

図15 $L_{m}$ とKのばらつき

表 1 各試料重量におけるKのばらつき

\begin{tabular}{r|c|c|c|c}
\hline $\begin{array}{c}\text { 試料重量 } \\
W(\mathrm{~g})\end{array}$ & $\begin{array}{c}\text { 実験回数 } \\
n\end{array}$ & $\begin{array}{c}\text { 平均試料層長さ } \\
L_{m}(\mathrm{~cm})\end{array}$ & $\begin{array}{c}K \text { の平均值 } \\
K_{m}\end{array}$ & $\begin{array}{c}\text { 標準偏差 } \\
\boldsymbol{\sigma}\end{array}$ \\
\hline 200 & 210 & 3.968 & 4.478 & 0.3234 \\
430 & 90 & 8.737 & 4.584 & 0.1844 \\
860 & 90 & 17.611 & 4.602 & 0.1168 \\
1,290 & 80 & 26.456 & 4.582 & 0.0883 \\
\hline
\end{tabular}

その通路を毛細管と考光，粉体層を毛細管の集合体として扱う。 このとき, 毛細管の長さを $L_{e}$, 粉体層長さを $L$ とすると, 実際は 通路はねじれているので，その通路を毛細管に置き換える場合， 
毛細管の長さは試料層の長さより長いことになる。よって， $L<$ $L_{e}$ であり, (3)式の Kozeny 定数 $K$ は以下のように置き換えるこ とができる゙）。

$$
K=k_{0}\left(L_{e} / L\right)^{2}
$$
(11)

ここで， $k_{0}$ はその通路の断面の形に依存する定数， $L / L_{e}$ はね じれ率である。すなわち, Kozeny 定数Kは, 充填層中の流路の “ねじれ”, すなわち, 試料層長さ $L$ と毛細管の長さ $L_{e}$ の比と断 面の形状に関係する。そして, Carman は「1インチのガラス管 に1/4インチのガラス球の充媜層をつくり，水を垂直下方に流し， そこにカラーバンドを入れた。層流条件に保つと，大部分が管軸 に対して $45^{\circ}$ の角度になった。」ことから, 半実験的に $k_{0}=2.5$ ， $L_{e} / L=\sqrt{2}$ として $K=5$ としている ${ }^{4)}$ 。

しかし，図15に示されるように，今回の実験結果を見る限りで は, $K$ は 5 という一定值をとる定数とは言い難く, かなりのばら つきを持った值で，そのばらつきは正規分布を示しているといえ る。

試料セルや実験装置, 使用した気体など実験条件を一定に保っ たまま同じ試料を測定したにもかかわらず，Kの值は変化してい るのだが,このことは，次のように考えることができる。

もし, Carmanの言うように ${ }^{4)}$ ，流体が試料層に対して常に $45^{\circ}$ の角度で流れるのであれば, 常に $L_{e} / L=\sqrt{2}$ となり, $K$ は 5 の一定值を保つ。しかし, 試料層中を流体が通る場合, その通 る道筋が詰め替えを行うたびに変わるのであれば，すなわち， (11)式において $L_{e} / L$ すなわちねじれ率の逆数が非常に不安定な数 值であれば，Kは一定值をとらないことになり $K=5$ にはならな いと考えるごとができる。

\section{8. ま と め}

粉体の比表面積を求めるための Kozeny-Carman 式中の Kozeny 定数 $K$ を検討するため, 比表面積および密度を正確に求 めた整粒球形ガラスビーズを用いてKを逆算する実験を繰り返し た。その結果, 以下のことがわかった。

(1) 試料重量を, $200 \mathrm{~g}, 430 \mathrm{~g}, 860 \mathrm{~g}, 1,290 \mathrm{~g}$ とし, それぞれ の実験回数を, $210,90,90,80$ 回繰り返した時に得られた定数 $K$
のそれぞれの平均值 $K_{m}$ は, $4.478 \pm 0.3234,4.584 \pm 0.1844$, $4.602 \pm 0.1168,4.582 \pm 0.0883$ であった。つまり, Kozeny 定数 は, その值もばらつきの程度も試料層の長さに依存している。

(2) 同一条件下での数多くの実験の結果, Kozeny 定数は,ばら つきを持った值となり，そのばらつきの分布は正規分布に従う。

以上，現時点で分かったことであるが，今後はさらに，これ以 外にどのような因子が Kozeny 定数に影響を与えるのかを検討す る必要があると考える。

謝辞本研究を開始した1971年から現在まで, 九州大学工学 部資源工学科資源処理工学講座の一員として本研究にご協力いた だいた多くの学生, 院生, 教職員の方々に厚く感謝の意を表する。

\section{参 考 文 献}

1）粉体工学研究会: 粒度測定技術, 281 298, (1975)，日刊工業新 聞社 (東京)

2）井伊谷鋼一：粉体工学ハンドブック，65 80, (1965), 朝倉書店 (東京)

3) 久保輝一郎他 : 粉体理論と応用, $161 \sim 175,(1962)$, 丸善（株） (東京)

4) Carman, P.C.: Trans. Inst. Chem. Eng., 15, 150 $166,(1937)$

5) Lea, F.M. and Nurse, R.W. : J. Soc. Chem. Ind., $58,277 \sim 279,(1939)$

6) Allen, T.: Particle Size Measurement 3d ed., 441 442 , (1981), Chapman and Hall( London)

7）日本化学会 : 化学便覧 基礎編 2 改訂 2 版, $2 \cdot 39,(1984)$, 丸善（株）（東京）

8) Perry, Robert H., Green, Don W. and Marony, James O. : Perry's Chemical Engineers's Handbok (Sixth Edition), 3·249, (1984), McGraw Hill Book Company

9) Allen, T.: Particle Size Measurement 3d ed., 432 435, (1981), Chapman and Hall (London)

10）東京天文台：理科年表 (昭和六十三年)，797，(1987)，丸善 (株) (東京)

11）森 肇・岡本寿夫：計算物理学 (日本物理学会編)， $87 \sim 97$, (1991), 培風館 (東京)

12) Mori, H., Hata, H., Horita, T. and Kobayashi, T. : Prog. Theor. Phys. Supplement, 99, 1-63, (1990) 